\title{
The role of customer satisfaction in mediating the effect of the evaluation of the bank's compliance with Islamic law on the continuous intention to use Islamic banking among coastal communities
}

\author{
Syafruddin Chan $^{1 *}$, Cut Aprilia ${ }^{1}$, and Jalaluddin Jalaluddin ${ }^{2}$ \\ ${ }^{1}$ Management Department, Faculty Economic and Business, Universitas Syiah Kuala, Indonesia \\ ${ }^{2}$ Accounting Department, Faculty Economic and Business, Universitas Syiah Kuala, Indonesia
}

\begin{abstract}
This study aims to analyze the factors that cause low intention of Islamic bank customers to continue using banks' services, especially among those who live in coastal areas. The population in this study is the coastal community who are customers of Islamic banks and domiciled in the coastal areas of Aceh and North Sumatra. The sample size in this study was 200 respondents (Hair, 2009). Sampling was done by stratified random sampling method with the following proportions: Aceh 40\%, North Sumatra 60\%. In this study, the sampling method used the census technique. Data analysis used SEM (Structural Equation Modelling) to verify the path of the relationship between variables in this study using IBM SPSS-AMOS software version 22. The results showed that Of the 3 direct hypotheses tested, the effect of Evaluation of bank's compliance with Islamic law on Customer satisfaction, the effect of Evaluation of bank's compliance with Islamic law on Continuous Intention to Use Islamic Banking and The effect of Customer Satisfaction on Continuous Intention to Use Islamic Banking, all of which show a significant effect. On the indirect effect tested, the effect of Evaluation of bank's compliance with Islamic law on Continuous Intention to Use Islamic Banking mediated by Customer Satisfaction has also a significant effect. In contrast to previous studies, which mostly analyzed the reluctance of customers to switch to sharia banks because of the profit motive, this study tries to look at the phenomenon of the reluctance of coastal communities to stay in Islamic banks, especially related to the aspect of compliance with Islamic law which is carried out by Islamic bank practitioners as seen from customer perceptions.
\end{abstract}

\section{Introduction}

\subsection{Research Background}

The growth of the Islamic banking industry in Indonesia is not as expected. The slowdown in the growth of Islamic banks can at least be seen from several indicators including Return on Assets (ROA), profitability and the ratio of financing to funding (finance to deposit ratio / FDR). The monthly ROA (\%) growth from August 2019 compared to August 2021 showed a downward trend from $1.64 \%$ to $1.38 \%$. Likewise the company's ability to generate profits by comparing them in the same period. Profitability in September 2019 was 1.83 while in September 2021 it also showed a decline to 1.36. Another indicator, namely the financing to deposit ratio (FDR) in the same period also decreased from 80.8 to 79,56 (Statistics of Islamic Banking - OJK, 2021). This phenomenon was also recognized by the Financial Services Authority (OJK) through the Deputy Commissioner for Banking Supervision of the Financial Services Authority (OJK) who stated that there was a slowdown in the growth of Islamic banks before and after the Corona virus
(COVID-19) pandemic (finance.detik.com, 8 November 2021).

The slowing growth in the performance of Islamic banks, both Islamic Commercial Banks (BUS) and Islamic Rural Banks (BPRS) cannot be separated from active the attractiveness of Islamic banking compared to conventional banking The customers are more logical, in determining the choice, which bank to trust as the bank where they invest and conducts their financial transactions. Research conducted by [1] reveals that religious motivation is not the dominant factor considered for choosing a sharia bank, but the bigger motivation is how much profit he gets from the activities he does. the investment [1]. This means that as long as their return on investment in conventional banks is higher than Islamic banks, then they will choose a conventional bank as a place for them to make transactions and financial investments. Another identified reason as the cause of people's reluctance to switch to Islamic banks is the indication that Islamic banks are still carrying out the concept of bank interest even though they are wrapped in different terms [2].

The public's reluctances to access Islamic banking products and services are evidenced by the emergence

* Corresponding author: syafruddin.chan@unsyiah.ac.id 
of understanding and expressions from several groups such as: Islamic banks are no different from conventional banks, borrowing from Islamic banks or Baitul Mal wat Tamwil (BMT) is more expensive than conventional banks or financial institutions. Another thing identified as the cause of people's reluctance to switch to Islamic banks is the indication that Islamic banks are still carrying out the concept of bank interest even though they are wrapped in different terms [2] . The public's reluctance to access Islamic banking products and services is evidenced by the emergence of understanding and expressions by several groups, such as: Islamic banks are no different from conventional banks, borrowing from Islamic banks or Baitul Mal wat Tamwil (BMT) is more expensive than conventional banks or financial institutions. Another thing identified as the cause of people's reluctance to switch to Islamic banks is the indication that Islamic banks are still carrying out the concept of bank interest even though they are wrapped in different terms [2]. The public's reluctance to access Islamic banking products and services is evidenced by the emergence of understanding and expressions by several groups, such as: Islamic banks are no different from conventional banks, borrowing from Islamic banks or Baitul Mal wat Tamwil (BMT) is more expensive than conventional banks or financial institutions [2].

The purpose of this study is to analyze customer evaluations of the application of the concept of sharia in sharia banking (evaluation of the bank's compliance with Islamic law) which is the expectation of many bank customers in an effort to encourage sustainable intentions in using sharia banking services for their customers to be the main issue raised in the study.

Many previous studies have discussed the determinant factors of repurchase intention towards Islamic bank products, as was done by [4] who found aspects of religiosity and bank reputation as the main determining factors to make customers of Sariah banks not switch to other banks. Then [5] who found the main factor for customers to stay in a bank because of perceived security concerns. Other researchers, namely [6] who reported the ease of use and speed of transaction variables as the dominant variables to increase customer interest in staying in a bank.

In contrast to previous research, this study tries to look at the phenomenon of community reluctance, especially coastal communities, to survive in Islamic banks, especially related to the aspect of compliance with Islamic law which is carried out by Islamic bank practitioners from the customer's perspective. This is important to do because, as previously indicated by previous researchers, there are customers who consider Islamic banking practices no different from conventional banks [2], or borrowing from Islamic banks is more expensive than from Islamic banks [3]. Coastal communities are defined as groups of people who live in coastal areas and whose sources of economic life depend directly on the utilization of marine and coastal resources. They consist of owner fishermen, fishing workers, cultivators of fish and other marine organisms, fish traders, fish processors, suppliers of fishery production facilities. In the non-fishery sector, coastal communities can consist of sellers of tourism services, sellers of transportation services, and other community groups who use marine and coastal nonbiological resources to support their lives [7].

The results of this study will be a reference for banking practitioners to redesign their marketing strategy not only to retain existing customers but also to acquire more and more conventional customers switching to sharia. In addition, the output of this research also adds to the repertoire of references and contributes to the enrichment of marketing concepts, especially those related to customer retention in the banking industry. Thus, the market share of Islamic banks in Indonesia, which is only 5\% [3], nationally can continue to increase in the future.

\subsection{Formulation of the problem}

There is still a reluctance of people in Indonesia, including Aceh, to switch to Islamic banks and remain customers of Islamic banks, even for the Muslim community. This is evidenced by the still sluggish growth of Islamic banks as evidenced by the sloping growth curve of return on assets (ROA), finance to deposit ratio (FDR) and Profitability for the period August 2019 to August 2021 (Islamic Banking Statistics, 2021). Several factors suspected to be the cause of the low public interest in switching to Islamic banks such as the bank's compliance with Islamic law that has been identified for further exploration in this study.

\subsection{Research Objectives and Types of Outcomes}

The purpose of this study is to introduce a conceptual framework that can facilitate the exploration of the causes of people's reluctance to become customers of Islamic banks, both from the aspect of applying Islamic law and ease of transacting using multichannel moderated by perceived compatibility and customer satisfaction.

\section{Literature review}

\subsection{Equations should be centred and should be numbered with the number on the right-hand side.}

The discussion on Evaluation of the bank's compliance with Islamic law, cannot be separated from the variable Religious attitude towards Islamic Bank. With regard to retail banking services, previous research has shown that a number of factors influence repurchase intention and customer loyalty [8]. A study conducted by [9] examines these determinants, including the reasons customers intend to do business with Islamic banks in a sustainable manner. [10] also examined customer attitudes towards sharia banking compliance practices. Other researchers examine the evaluation of their compliance in their business practices with Islamic law, 
because customers consider the main reason to keep doing business is their religiosity motive [11].

Many studies related to the influence of Religious attitude towards Islamic Bank or Evaluation of bank's compliance with Islamic law on Continuous Intention to Use Banking (Repurchase Intention) in Islamic banks have been carried out, including by [10], [8] and [12]. Meanwhile, research related to the influence of Religious attitude towards Islamic Bank or Evaluation of bank's compliance with Islamic law on customer satisfaction has been conducted by [13].

H1: There is an effect of Evaluation of bank's compliance with Islamic law on customer satisfaction

H2: There is an effect of Evaluation of bank's compliance with Islamic law on Continuous Intention to Use Islamic Banking

\subsection{Customer satisfaction}

The concept of customer satisfaction and repurchase intention conceptually has been widely discussed and is one of the most popular theories in the field of marketing management. [14] suggests that satisfaction is mainly based on emotion rather than reasoning. He defines satisfaction as the fulfilment response of the consumer'. His statement is based on consumers' evaluations of the after-sales services of service providers and whether they meet the level of customer satisfaction or not. [15] on the other hand measure service and service satisfaction through seven components such as; interest, pleasure, surprise, anger, wise choice, and doing what is right. Because customer satisfaction is primarily based on emotion as previously pointed out by [14] it is natural that each person experiences emotions in different ways and therefore also assesses customer satisfaction in different ways. Research related to the effect of customer satisfaction on repurchase intention has been carried out by [16] and [10]

H3: There is an effect of customer satisfaction on Continuous Intention to Use Islamic Banking

\subsection{Continuous Intention to Use Islamic Banking}

According to [17] repurchase is described as a customer's real action in buying or reusing the product. Once, a customer buys an item, it has the potential to repeat the purchase [16]. This means that customers repeatedly consume similar services or products from similar sellers. While repurchase is an actual act, repurchase intention indicates the customer's decision to engage in future activities with retailers or suppliers [18]. Customer repurchase intention has been conceptualized in several recent studies based on two aspects namely repurchase intention and repurchase intention to engage in promotions and positive recommendations (referrals) [16].

H4: There is an effect of Evaluation of bank's compliance with Islamic law on Continuous Intention to Use Islamic Banking through customer satisfaction

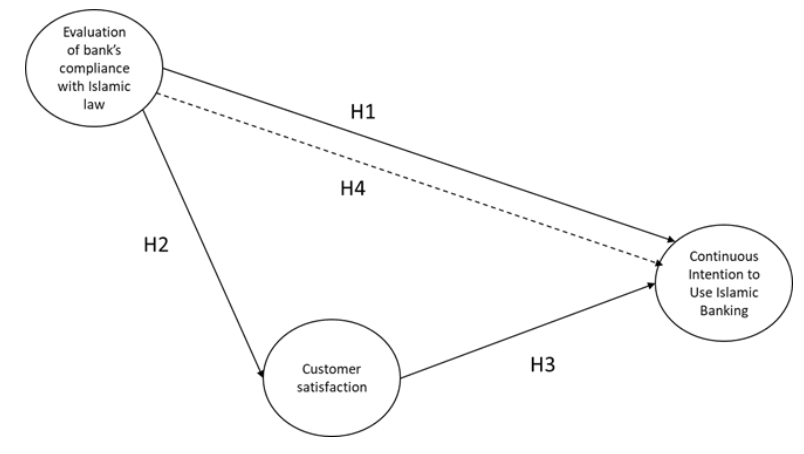

Fig. 1. Research Model

\section{Research methods}

\subsection{Research Instruments}

All measurement items were taken from previous studies to ensure validity; however, slight changes to the statement were made to suit the current analysis. The eight-item of Evaluation of bank's compliance with Islamic law was adapted from [9]. Four items adopted from [19] were used to measure customer satisfaction. Then five items are used to measure Continuous Intention to Use Islamic Banking was adopted from [16]. A questionnaire with a 5-point Likert scale was used to collect data. In addition, this study uses in-depth interviews with several sources (informants) who represent the elements of providers and customers.

\subsection{Sample Design and Data Collection}

The population in this study is the coastal community who are customers of Islamic banks and domiciled in the coastal areas of Aceh and North Sumatra. The sample size in this study was 200 respondents [20]. Sampling was done by stratified random sampling method with the following proportions: Aceh $40 \%$, North Sumatra $60 \%$. The proportion of North Sumatra is greater because the number of coastal communities who are customers of Islamic banks in North Sumatra is also greater than Aceh

\subsection{Data analysis}

The data analysis technique in this research is descriptive and verification. Descriptive analysis was conducted to assess the demographic profile of the respondents and the internal consistency of construction. While the verification analysis uses SEM (Structural Equation Modelling) to verify the path of the relationship between the variables in this study. In addition, the SEM analysis software is IBM SPSSAMOS version 22.

\section{Results and Discussion}

\subsection{Characteristics of Respondents}

In terms of age, the most respondents came from the age group 31-35 years, namely 42 (34.7\%). From gender, there are more men than women, namely $83(68.6 \%)$. 
Then from the education group the most are those with undergraduate education, namely $60(49.6 \%)$. The majority of their jobs are in the fishery sector $(60 \%)$, the rest $(40 \%)$ work outside the fisheries sector such as trade, culinary and other tourism services.

\subsection{Validity with Measurement Model}

An indicator is said to be valid if it has a standardized loading factor value $>0.50$. For indicators that do not meet the requirements will be eliminated from the model. From the calculation results, it turns out that there are 5 indicators that do not meet the requirements because they have a loading factor number below the required one, namely 0.5 . So indicators a1, a2, a16 and a23 must be eliminated.

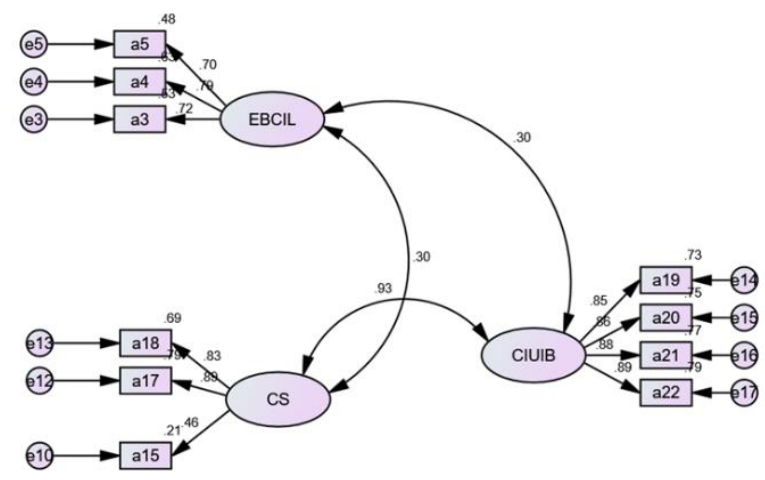

Fig. 2. Measurement Model

The new loading factor after elimination can be seen in the table below.

Table 1. New Loading Factor

\begin{tabular}{|ccc|c|}
\hline Item & & Var & Estimate \\
\hline a3 & $<---$ & EBCIL & .725 \\
a4 & $<---$ & EBCIL & .793 \\
a5 & $<---$ & EBCIL & .695 \\
a15 & $<---$ & CS & .463 \\
a17 & $<---$ & CS & .887 \\
a18 & $<---$ & CS & .832 \\
a19 & $<---$ & CIUIB & .853 \\
a20 & $<---$ & CIUIB & .865 \\
a21 & $<---$ & CIUIB & .878 \\
a22 & $<---$ & CIUIB & .891 \\
\hline
\end{tabular}

Based on the table above, it can be explained that all the variable items used in this study are all valid, because they have a loading factor number $>0.50$.

\subsection{Reliability Test}

The reliability test intended in this study is to determine the extent to which the measurement results remain statistically consistent, namely by calculating the magnitude of the composite reliability of the data based on the estimated output obtained using Cronbach alpha. The results are as described in Table 4.3 which shows that the instrument in this study is reliable because its reliability coefficient value is greater than 0.60 [21].
Based on the reliability analysis, it can be seen that the alpha for each respondent's perception variable can be seen from several variables the bank's compliance with Islamic law is $74.5 \%$, Customer satisfaction is $79.8 \%$, and Continuous Intention is $88.3 \%$. Thus the reliability measurement of the research variables shows that the reliability measurement meets the requirements of Cronbach Alpha (CA) where the CA coefficient value is at least or greater than 60 percent.

Table 2. Reliability Using Cronbach Alpha (CA)

\begin{tabular}{|c|c|c|c|c|}
\hline $\begin{array}{c}\mathrm{N} \\
\mathrm{o}\end{array}$ & Variable & $\mathrm{CA}$ & Items & Desc. \\
\hline 1 & $\begin{array}{c}\text { Evaluation of the } \\
\text { bank's compliance } \\
\text { with Islamic law }\end{array}$ & .745 & 5 & Reliable \\
\hline 4 & $\begin{array}{c}\text { Customer } \\
\text { satisfaction }\end{array}$ & .798 & 4 & Reliable \\
\hline 5 & $\begin{array}{c}\text { Continuous } \\
\text { Intention to Use } \\
\text { Islamic Banking }\end{array}$ & .883 & 5 & Reliable \\
\hline
\end{tabular}

\subsection{Hypothesis Testing}

Hypothesis test verification in this study was conducted to test and analyze the effect of Evaluation of the bank's compliance with Islamic law, Customer satisfaction, and Continuous Intention to Use Islamic Banking. The verification hypothesis testing consists of testing the direct influence hypothesis and testing the indirect effect hypothesis. The results of testing the direct influence hypothesis can be seen in the following figure and table.

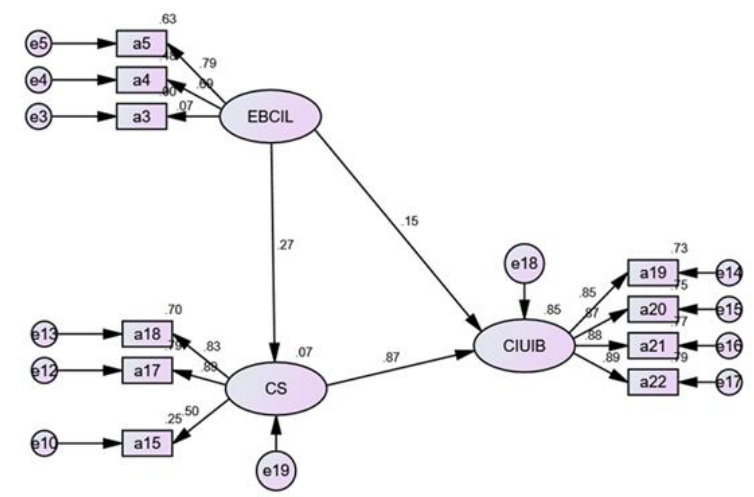

Fig. 3. Structural Model

Table 2. Hypothesis Testing

\begin{tabular}{|lll|lll|}
\hline Variables & & & CR & P & Beta \\
\hline CS & $<---$ & EBCIL & 2.406 & .016 & .269 \\
CIUIB & $<---$ & EBCIL & 8,620 & $* * *$ & .153 \\
CIUIB & $<---$ & CS & 8,629 & $* * *$ & .871 \\
\hline
\end{tabular}

EBCIL: Evaluation of the bank's compliance with Islamic law CS: Customer satisfaction

CIUIB: Continuous Intention to Use Islamic Banking

H1: The effect of Evaluation of bank's compliance with Islamic law on Customer satisfaction 
Testing the effect of Evaluation of bank's compliance with Islamic law on Customer satisfaction shows a CR value of 2.406 and with a probability of .016. The two values obtained have met the requirements for the acceptance of $\mathrm{Ha}$, namely the $\mathrm{CR}$ value greater than 1.96 and the probability less than 0.05 . The magnitude of the coefficient of the effect of Evaluation of bank's compliance with Islamic law on Customer satisfaction is 0.269

H2: The effect of Evaluation of bank's compliance with Islamic law on Continuous Intention to Use Islamic Banking

Testing The effect of Evaluation of bank's compliance with Islamic law on Continuous Intention to Use Islamic Banking shows a CR value of 8,620 and with a probability of $* * *$ Thus it can be stated that the effect of Evaluation of bank's compliance with Islamic law on Continuous Intention to Use Islamic Banking is significant. The magnitude of the coefficient of the effect of Evaluation of bank's compliance with Islamic law on Continuous Intention to Use Islamic Banking is 0.153

\section{H3: The effect of Customer Satisfaction on Continuous} Intention to Use Islamic Banking

Testing The effect of Customer Satisfaction on Continuous Intention to Use Islamic Banking shows a CR value of 8,629 and with a probability of ***. The two values obtained have met the requirements for acceptance of Ha. The magnitude of the coefficient of the effect of Customer Satisfaction on Continuous Intention to Use Islamic Banking is 0.871

H4: The effect of Evaluation of bank's compliance with Islamic law on Continuous Intention to Use Islamic Banking through Customer Satisfaction

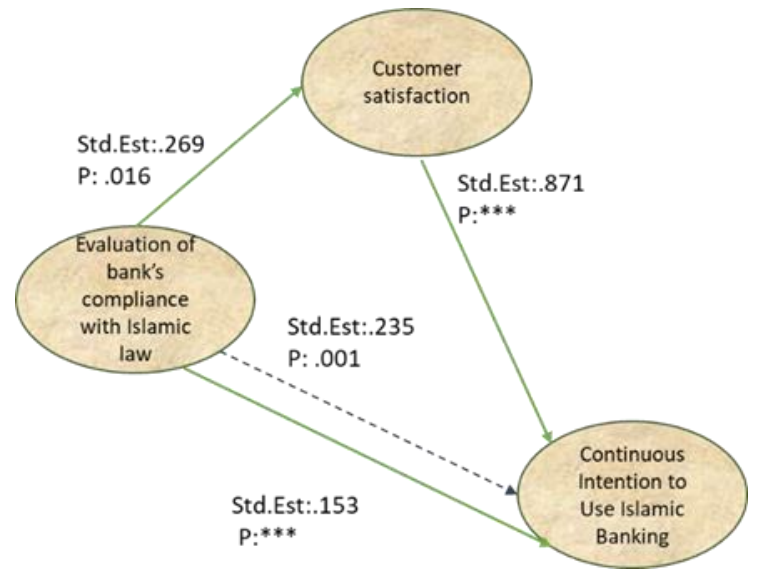

Fig. 5. The effect of Evaluation of bank's compliance with Islamic law on Continuous Intention to Use Islamic Banking through Customer Satisfaction

Testing the influence of Evaluation of bank's compliance with Islamic law on Continuous Intention to Use Islamic Banking through Customer Satisfaction shows a probability of .002 . The $\mathrm{p}$ value obtained has met the requirements for acceptance. Ha. The coefficient of the effect of Evaluation of bank's compliance with Islamic law on Continuous Intention to Use Islamic Banking through Customer Satisfaction is 0.235 or $23.5 \%$.

Because the effect of Evaluation of bank's compliance with Islamic law on Continuous Intention to Use Islamic Banking is significant and the effect of Evaluation of bank's compliance with Islamic law on Continuous Intention to Use Islamic Banking through Customer Satisfaction is significant, we can say that the role of Customer Satisfaction in mediating these two variables is Partial Mediating.

\section{Discussion}

Of the 3 direct hypotheses tested, the effect of Evaluation of bank's compliance with Islamic law on Customer satisfaction, the effect of Evaluation of bank's compliance with Islamic law on Continuous Intention to Use Islamic Banking and The effect of Customer Satisfaction on Continuous Intention to Use Islamic Banking, all of which show a significant effect. The significance that occurs in this direct test indicates that there is a match between the research model developed and the facts in which this research was conducted.

Based on the results or findings presented in the previous section, it means that Evaluation of bank's compliance with Islamic law and Customer satisfaction are indeed a determinant variable of improving the intention of bank's customer to continue using Islamic banking. So that the management can use these two variables as tools to improve the intention of the bank's customer to continue using Islamic banking. This is in line with research conducted by [22]. The phenomenon of the tendency of customers to switch to other banks should be addressed because of the low level of satisfaction. Low satisfaction means that customers' expectations of banking services are not fully obtained. From the research conducted by [3] it was revealed that there was dissatisfaction of Islamic bank customers with the level of profit they got after investing in Islamic banking products. On the other hand, the costs incurred when using transaction facilities provided by Islamic banks are also relatively high compared to conventional banks. Not to mention the cost of borrowing funds that they have to pay, the cost of funds is also relatively higher than conventional banks. The various facts that they mostly feel are below their expectations so that it has an impact on their dissatisfaction with the offerings made by Islamic banks. Of course this will have an impact on their desire to switch to competitors.

In order to support the strongest increase in the intention to use Islamic banking services, it can be done through the increasing of customer satisfaction, because this variable has the largest magnitude number compared to the other variables, namely $87.1 \%$ compared to the bank's compliance with Islamic law which is only $26.9 \%$ On the indirect effect tested, although it showed significant results, the role of customer satisfaction in mediating the effect of Evaluation of bank's compliance with Islamic law on Continuous Intention to Use Islamic Banking is quite 
good. The path of the effect of Evaluation of bank's compliance with Islamic law on Continuous Intention to Use Islamic Banking mediated by Customer Satisfaction has a coefficient of $23.5 \%$.

\section{Conclusion}

From the discussion that has been carried out in the previous section, research findings related to hypothesis testing were carried out either directly or indirectly. In principle, the model built is based on a literature review and preliminary research based on references related to the field under study, in this case improving the intention of Islamic bank customer to continue using Islamic bank services. . Based on the literature review, a research model was built as presented in the previous section in this research paper. And in fact, after going through a series of tests, it turned out that all the hypotheses that were built involving the Bank's compliance with Islamic law, Customer satisfaction and Continuous Intention to Use Islamic Banking variables proved significant and had a positive effect.

For further research development, variable synthesis can also be added to create new variables from the results of the synthesis of two or more variables in this study. The synthesis of these variables must of course be carried out based on existing field facts combined with theoretical concepts related to the variables to be synthesized, which can influence customers to use goods or services from the Islamic banking.

\section{References}

1. C. Erol, El-Bdour R, Int J Bank Mark. (1989)

2. A. Al-Mawarid, J Islam Law 10 (2003)

3. S. Bahri, Iqtishaduna, J Ilm Ekon Kita. 9, 1 (2020)

4. N. Tara, M. Irshad, M.R. Khan, M. Yamin, M. Rizwan, J Public Adm Gov 4, 3 (2014)

5. H. S. Yoon, L. Occeña, J Comput Inf Syst 54, 3 (2014)

6. A. L. N. Chima, V. K. Chikasanda, The Impact of Internet Banking on Service Quality Provided by Commercial Banks [Internet]. Lecture Notes of the Institute for Computer Sciences, Social Informatics and Telecommunications Engineering. (Springer International Publishing, 2014)

7. C. T. Karubaba, G. B. Dietriech, V. P. Nikijuluw, Indones J Coast Mar Resour 3, 3 (2001)

8. N. Alam, M. S. Rajjaque, Shariah-Compliant Equities: Empirical Evaluation of Performance in the European Market during Credit Crunch. Islamic Finance. (Springer International Publishing, 2016)

9. H. Kamiyama, K. Kashiwagi. J Financ Serv Mark 24, 3-4 (2019)

10. H.M. Awan, K. Shahzad Bukhari. J Islam Mark 2, $1(2011)$

11. N. Souiden, M. Rani, Int J Bank Mark 33, 2 (2015)

12. S.N. Maswadeh, Procedia Econ Financ 23 (2015)
13. K. Naser, A. Jamal, K. Al-Khatib, Int J Bank Mark 17, 3 (1999)

14. R. L. Oliver, Customer Satisfaction with Service [Internet]. Handbook of Services Marketing \& Management. SAGE Publications, Inc.; p. 247-54.

15. J. J. Cronin, M.K. Brady, G. T. M. Hult, J Retail 76, 2 (2000)

16. N.K. Mu'azu Saidu Badara, N. Mat, A.M. Mujtaba, A.N. Al-Refai, A.M. Badara, F.M. Abubakar, Management 3, 1 (2013)

17. H. Herjanto, M. Amin, Int J Bank Mark 38, 6 (2020)

18. J. Kandampully, D. Suhartanto, Int J. (2000)

19. R.L. Oliver, J Mark [Internet] 63 (1999)

20. J.F. Hair, W.C. Black, B.J. Babin, R.E. Anderson, R.L. Tatham, Multivariate data analysis 6 th Edition (New Jersey, Prentice Hall, 2006)

21. L.R. Kahle, N.K. Malhotra, J Mark Res 31, 1 (1994)

22. M. Brady, J. Cronin, R. Brand, J Bus Res, (2002) 